\title{
EXPERIMENTAL PERFORMANCE CHARACTERIZATION AND ECONOMIC EFFICIENCY OF 16.28 KWP GRID-TIED PV SYSTEMS IN SEMI-ARID CLIMATE
}

\author{
Messaouda Benbitour KHENNANE ${ }^{1,2}$, Slimane BOUGHALI ${ }^{1}$, Djamel BECHKI ${ }^{1}$, Layachi ZAGHBA ${ }^{2}$, \\ Amor FEZZANI ${ }^{2}$, Idriss Hadj MAHAMMED ${ }^{2}$ \\ ${ }^{1}$ Laboratoire des Energies Nouvelles et Renouvelables dans les Zones Arides (LENREZA), Faculté des Sciences \\ et de la Technologie et des Sciences de la Matière, Université Kasdi Merbah Ouargla, Ouargla 30000 \\ (Algérie). layachi.zaghba@gmail.com; Algeria \\ ${ }^{2}$ Unité de Recherche Appliquée en Energies Renouvelables, URAER, Centre de Développement des Energies \\ Renouvelables, CDER, 47133, Ghardaïa, Alegria.
}

\begin{abstract}
The study of the paper aims to present a solar power plant performances and economic benefits of 16.28 kWp grid-tied solar PV systems under the real outdoor conditions of Ghardaïa, located in semi-arid area of the Algeria desert. The main goal of this study is to investigate the effectiveness, suitability, feasibility and reliably of these plants on the level of desert areas and under the influence of harsh conditions (desert environment) in the first part. In the second part, the contribution of solar PV plant to conventional networks in the arid and semi-arid environment to assess the rate of integration. Based on experimental measurement data, the paper also shows economic benefits of three photovoltaic plants. It was found that from the first January to last August 2019, the total produced energy by all PV arrays was $171.422 \mathrm{MWh}$ which supplied to the internal grid and while, the consumed energy by the URAER unit was 159,094 kWh. Approximately 10, $95 \%$ of the $159,094 \mathrm{MWh}$ energy consumed in the whole year is provided from the generated PV solar energy that is $17,422 \mathrm{MWh}$. The total energy fed to the internal grid has grown from $27 \mathrm{MWh}$ in 05/04/2018 to a maximum of $67.28 \mathrm{MWh}$ recorded in 31/10/2019. The rate of integration of solar energy by all PV arrays in the internal network of the URAER varied between $6,60 \%$ in January and 22, 96\% in April. The integration of this renewable energy generation into the local grid in the URAER unit considered satisfactory over this period of operation. From the first January to last August 2019, the cost of electrical energy produced by solar plants is 2090,64 euro(277706,68 Algerian dinars) while the cost of energy consumed by the Applied Research Unit in renewable energies is 4772,82 euro(664853,826 Algerian dinars).
\end{abstract}

Keywords: Grid connected PV system; performance evaluation; Sandstorm, Saharan environment, Economic benefits.

\section{INTRODUCTION}

In a rapidly changing global energy context marked by a decrease in conventional fossil fuels and ever-increasing greenhouse gas emissions, the development of renewable energies remains the most effective bulwark. The global electricity generation capacity of PV has raised from $40 \mathrm{GW}$ in 2010 to $415 \mathrm{GW}$ in 2017 [1]. Of all renewable energies, solar photovoltaic (PV) is of particular interest for Algeria, since it has a solar deposit favorable to the development of this form of energy. Currently, the global installed capacity is about $344 \mathrm{MWp}$ according to the Electricity \& Renewable Energy Company, SKTM [2]; (www.sktm.dz). The most of these plants are located in arid under the external severe climate such (heat, sands, soiling, dust) and, there is no reliable model to predict instantaneous electricity production [3, 4]. PV systems are in accelerated aging conditions and degradation compared to installations in humid climatic zones $[5$,
6]. Several studies have been conducted on the evaluation of the performance of PV solar power plants installed worldwide. Various efforts are made by the research community for assessing the performance of PV solar power plants. Some of the results relevant are summarized as follows. Environmental impacts on the performance of solar photovoltaic systems. Four environmental factors (the accumulation of dust, water droplets, birds' droppings, and partial shading conditions) affecting system performances are investigated. It was found that dust accumulation reduced the power output by $8.80 \%$ and the efficiency by $11.86 \%$, while birds fouling the PV module surface was found to reduce the PV system performance by about 7.4\% [7]. Makrides et al evaluated 13 different photovoltaic technologies in two localities (Nicosia, Cyprus and Stuttgart, Germany), all connected to the network with the power of $1 \mathrm{kWp}$. The results have shown that the highest energy yields $(1580 \mathrm{kWh} / \mathrm{kWp})$ compared to those installed at Stuttgart (1194 kWh $/ \mathrm{kWp}$ ) [8]. Kymakis et al conducted a study on the 
analysis of the performance of a power plant connected to the network $171.36 \mathrm{kWp}$ electric powers on Crete Island, Greece in 2002. Monitoring of this PV system was carried out during a year: the performance report and the different power losses (temperature, dust, electrical network, availability of network) have been calculated. Final yield (Yf) varies between 1.96 and 5.07 hours per day and the performance report between 58 to $73 \%$ with an annual ratio of $67.36 \%$ [9]. Behiri et al presents an experimental investigation for performance evaluation and energy efficiency estimation of a specific grid connected photovoltaic power system under real meteorological conditions installed in Ma'an, Jordan. The grid connected photovoltaic power system was considered satisfactory during this period, where the annual energy efficiency of the OPVP was $12.1 \%$, the average annual value of the performance ratio was $78.14 \%$, and the average annual capacity factor was $26.34 \%$ [10] .A more recent study by Sharma et al focused on the evaluation of the performance of different PV technologies made of polycrystalline silicon, thinfilm and amorphous silicon at the Center for Solar Energies in India. To do this, the energy efficiency and performance reports have been calculated. The performance comparison concluded that the thin film and amorphous silicon technology performed better [11]. Performance of for connected PV system is highly sensitive to the operating temperature. Performance enhancement of grid-tied PV system through proposed design cooling techniques: An experimental study and comparative analysis [12]. Depending on the various works carried out on the topic, the purpose of our work is to assess the performance and economic benefits of $16.28 \mathrm{kWp}$ grid-tied solar PV systems under extreme climate conditions in a desert region from the south of Algeria (semi-arid conditions).

\section{PHOTOVOLTAIC ARRAY MODELING}

The equivalent circuit of the PV cell (single diode model) is presented in Fig. 1. The output current of the photovoltaic generator is given by the following expression $[13,14]$ :

$$
I=I_{p h}-I_{0} N_{p p}\left[\exp \left(\frac{V+R_{s}\left(\frac{N_{S s}}{N_{p p}}\right) I}{V_{t} a N_{s s}}-1\right)\right]-\frac{V+R_{s}\left(\frac{N_{S s}}{N_{p p}}\right) I}{R_{P}\left(\frac{N_{S s}}{N_{p p}}\right)}(1)
$$

Where, $I, I_{p h}$ and $I_{0}$ are the current array, the photo generated and the reverse current respectively. $V, V_{t}$ are the array ant the thermal voltage respectively. a, is the diode ideality factor. $R_{s}, R_{s h}$ are cell series and shunt resistance. $N_{s s}, N_{p p}$ are the number of modules in series and parallel.

The equation of the internal temperature of the cell is a function of the ambient temperature. The nominal operating temperature of the cell (NOCT) is as follows $[13,15]$ :

$$
T_{c}=T_{a}+\left(\frac{N O C T-20}{800}\right) G
$$

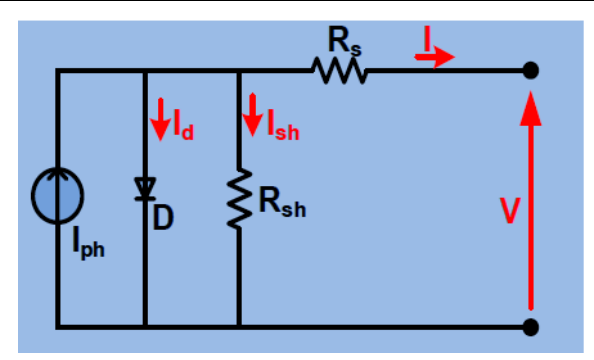

Fig 1. Equivalent circuit of a PV cell, single diode model

Where, $T_{a}$ is the ambient temperature and $T_{c}$ is the PV module temperature.

The experimental PV array efficiency is calculated using the following expression $[16,17]$ :

$$
\eta_{\text {exp }}=\frac{V_{d c^{I} d c}}{G A}
$$

Where, $V_{D C}$ is the PV voltage output, $A$ is the total area occupied by the PV array $\left(\mathrm{m}^{2}\right)$.

The PV array output power can be calculated using the following expression [18]:

$P=P_{s t c} \eta_{s t c} A\left[1-\delta\left(T_{c}-25\right)\right]$

Temperature effect on PV parameters can be calculated using the following expression [19][20]:

$\left\{\begin{array}{c}P_{m p p}(T)=P_{m p p}\left[1-\gamma\left(T-25^{\circ} C\right)\right. \\ V_{m p p}(T)=V_{m p p}\left[1-\beta\left(T-25^{\circ} C\right)\right. \\ I_{m p p}(T)=I_{m p p}\left[1-\alpha\left(T-25^{\circ} C\right)\right. \\ V_{o c}(T)=V_{o c}\left[1-\beta\left(T-25^{\circ} C\right)\right. \\ I_{s c}(T)=I_{s c}\left[1-\alpha\left(T-25^{\circ} C\right)\right.\end{array}\right.$

Where, $I_{m p p}$ and $V_{m p p}$ are short circuit current and open circuit voltage respectively at Standard Test Conditions. $V_{o c}$ and $I_{s c}$ are open circuit voltage and short circuit current respectively . $\alpha, \beta$ and $\gamma$ are the current/ temperature the voltage/temperature and power temperature/ coefficient respectively.

\section{POWER GAIN}

The performance of the system's power gain is calculated using the equation bellow [21]:

$P_{\text {Gain }}=\frac{P_{\text {track }}{ }^{-P_{\text {fix }}}}{P_{\text {track }}} \times 100$

Where, $P_{\text {track }}$ is the power output of the solar tracking system, $P_{f i x}$ the power output of a fixed solar system and $P_{\text {Gain }}$ is the power gain.

\section{EXPERIMENTAL SETUP}

This study focused on the desert environment, the experiment was carried out in the Applied Research Unit for Renewable Energies (URAER) located at Ghardaia, southern Algeria $\left(32,29^{\circ} \mathrm{N}-3,40^{\circ} \mathrm{E}\right)$, affiliated to the Renewable Energy Development Center (CDER). This power plants include three grid-tied PV systems, the first is a fixed power plant inclined with an angle of $32^{\circ}$ with a capacity of 2.25 $\mathrm{kWp}$ installed on the roof of parking car connected to the internal grid of URAER unit through an inverter sunny boy 3000 TL 20 working since 
October 2014 and the second is a dual-axis tracking solar power plant with a capacity of $2.25 \mathrm{kWp}$ tied to the internal grid of URAER unit through an inverter sunny boy $3000 \mathrm{HF}$, while the third power plant with a capacity of $11.28 \mathrm{kWp}$, contains three similar plants of $3.76 \mathrm{kWp}$ each connected to one of the 3 internal network phases of the unit through an inverter sunny boy 4000 TL. The purpose of these power plants is to know the effectiveness, suitability, reliably and economic efficiency of these plants on the level of desert areas and under the influence of harsh conditions for this environment (desert area). The objective also is to see the rate of integration and the energy contribution of solar PV to conventional networks under the arid and semi-arid environments.

Fig 2 shows a map that contains a PV plant installed at the field of Applied Research Unit for Renewable Energies (URAER), Ghardaia as a specific desert climate environment. [22, 23] .It has an extremely hot and dry climate throughout the year. Temperature ranges from $35^{\circ} \mathrm{C}$ to $45^{\circ} \mathrm{C}$ and exceeds $48^{\circ} \mathrm{C}$ in summer; rain is rare and low humidity rate. The months of March, April, and May are a transitional period in which sand storms occur, which leads to the accumulation of sand dust on the surfaces of solar panels [24, 25].

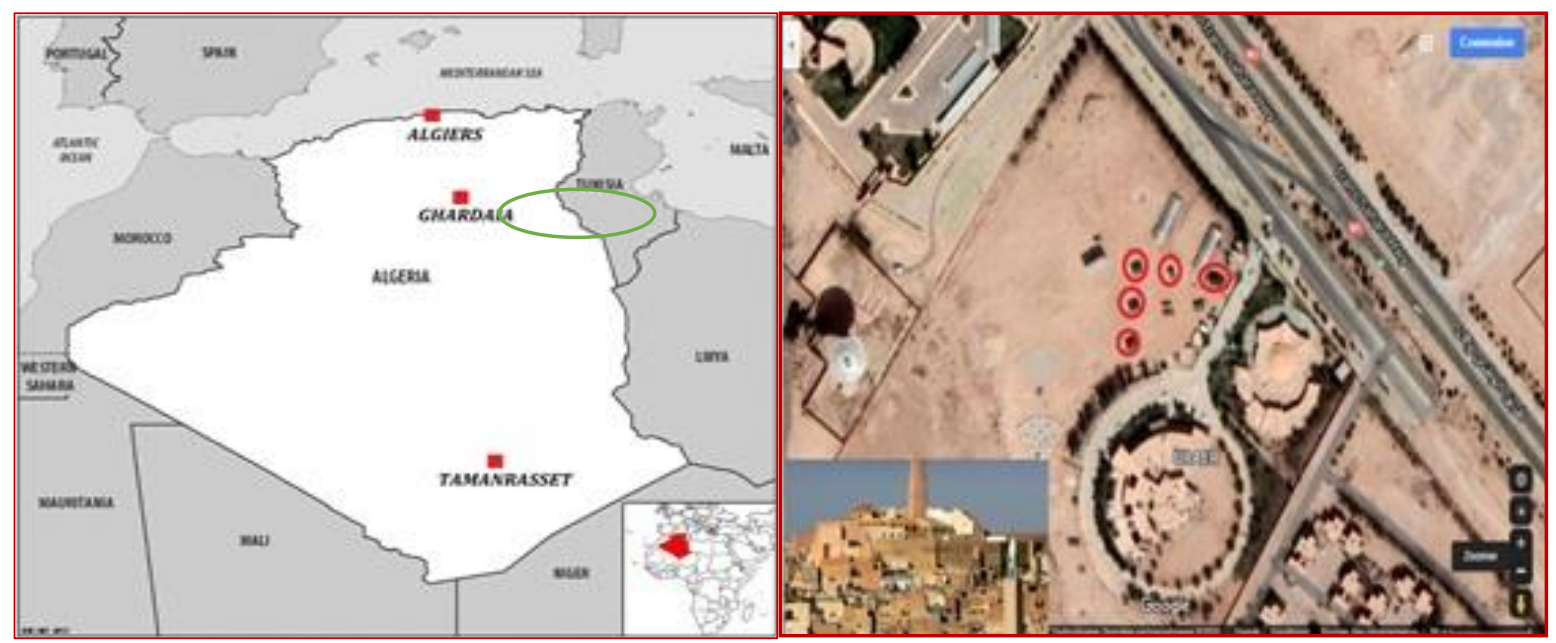

Fig. 2. Location of the power plant installed at Ghardaia, Algeria by Google Earth

A global diagram of all the Mini-power stations is represented by Fig 3 .

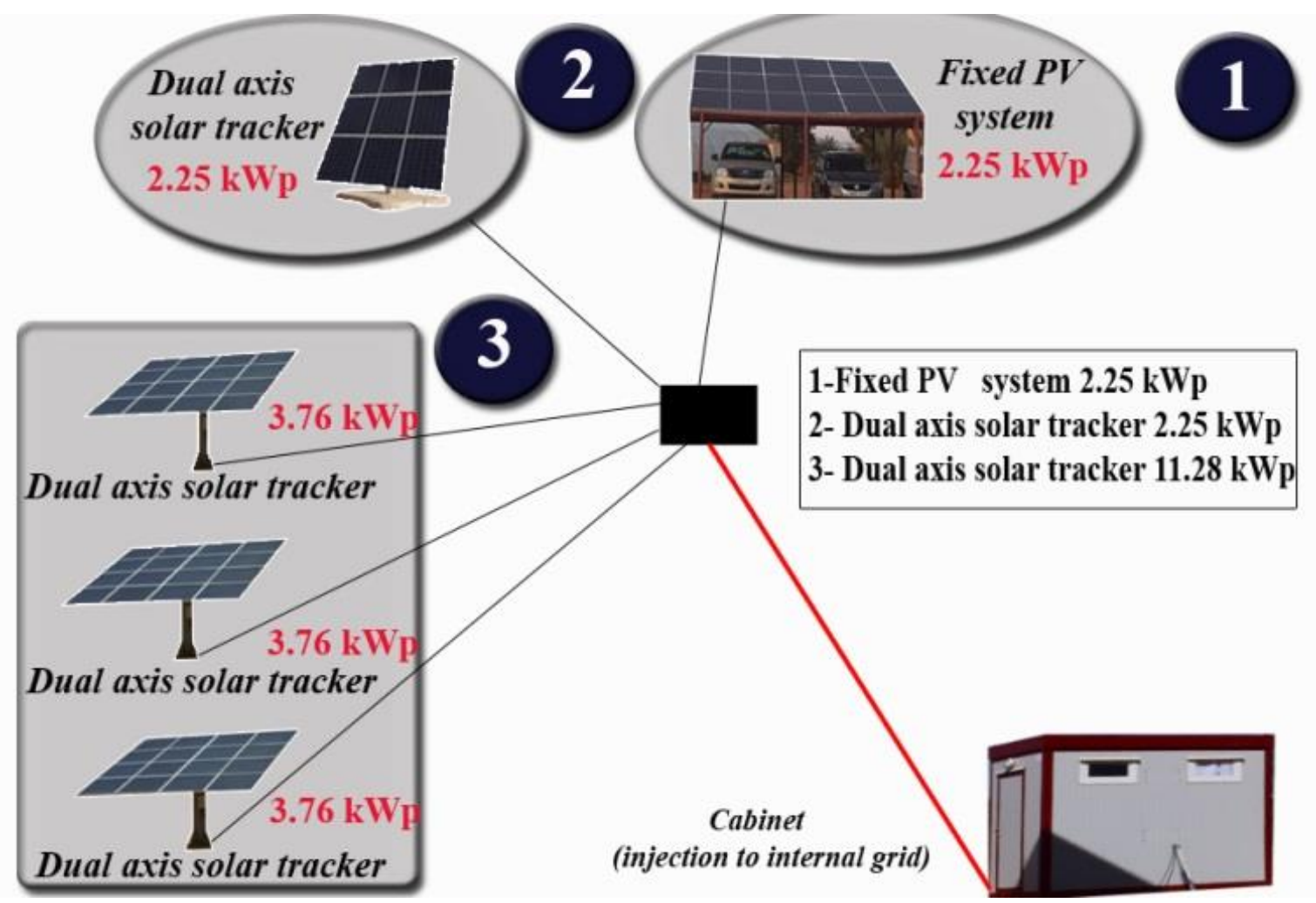

Fig. 3. Schematic of three grid-connected PV systems located in URAER, Ghardaia, Algeria. 


\subsection{Data monitoring and collection}

Agilent 34970A includes a multiplexer module Agilent 34902A with sixteen channels that were used to measure both the DC and AC electrical parameters of the PV array (energy, power, current, voltage, etc.). Also, the meteorological data (ambient temperature and global radiations) were measured using a thermocouple and a pyranometer (KIPP\&ZONEN CM11 type) respectively. These parameters are recorded with an interval of five minutes and saved on daily files. All the measured parameters are sent to the PC via the RS232 interface as shown in Fig 4.

\subsection{Description of the solar PV power plant}

4.2.1 First fixed mini-photovoltaic power plant

This grid-connected pilot photovoltaic power plant installed on the roof of parking, with a total power of $2.25 \mathrm{kWp}$, has fully injected the energy produced into was fed into the internal electrical of the URAER, since it was inaugurated on $10 / 14 / 2014$. It consists of 18 modules of amorphous silicon (thin film), of $110 \mathrm{Wp}$ each, mounted in 9 branches of two modules in series, the sunny boy SMA $3000 \mathrm{TL}$ inverter with two inputs of $150 \mathrm{~V}, 15 \mathrm{~A}$ and a singlephase output $220 \mathrm{~V} 50 \mathrm{~Hz}$.

Fig' 6 shows the characteristics I (V) and P (V) of the Inventux series $\mathrm{X}$ photovoltaic module at $\mathrm{T}=$ $25^{\circ} \mathrm{C}$ and $\mathrm{G}=1000 \mathrm{~W} / \mathrm{m}^{2}$.

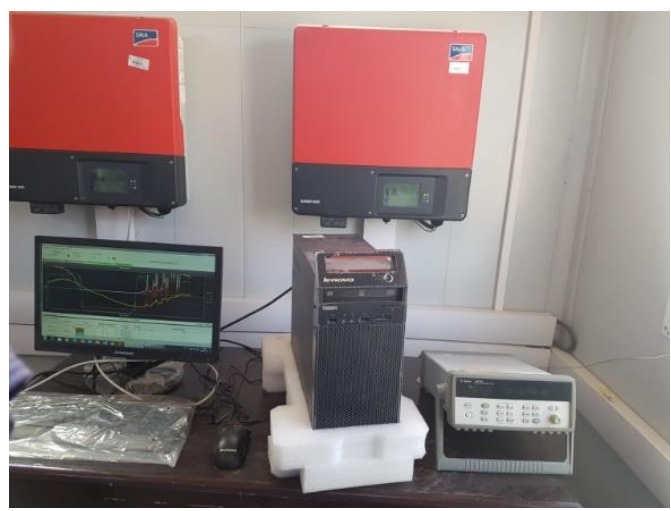

Fig. 4. Measurement data of both electrical and meteorological parameters using Agilent 34970A data logger

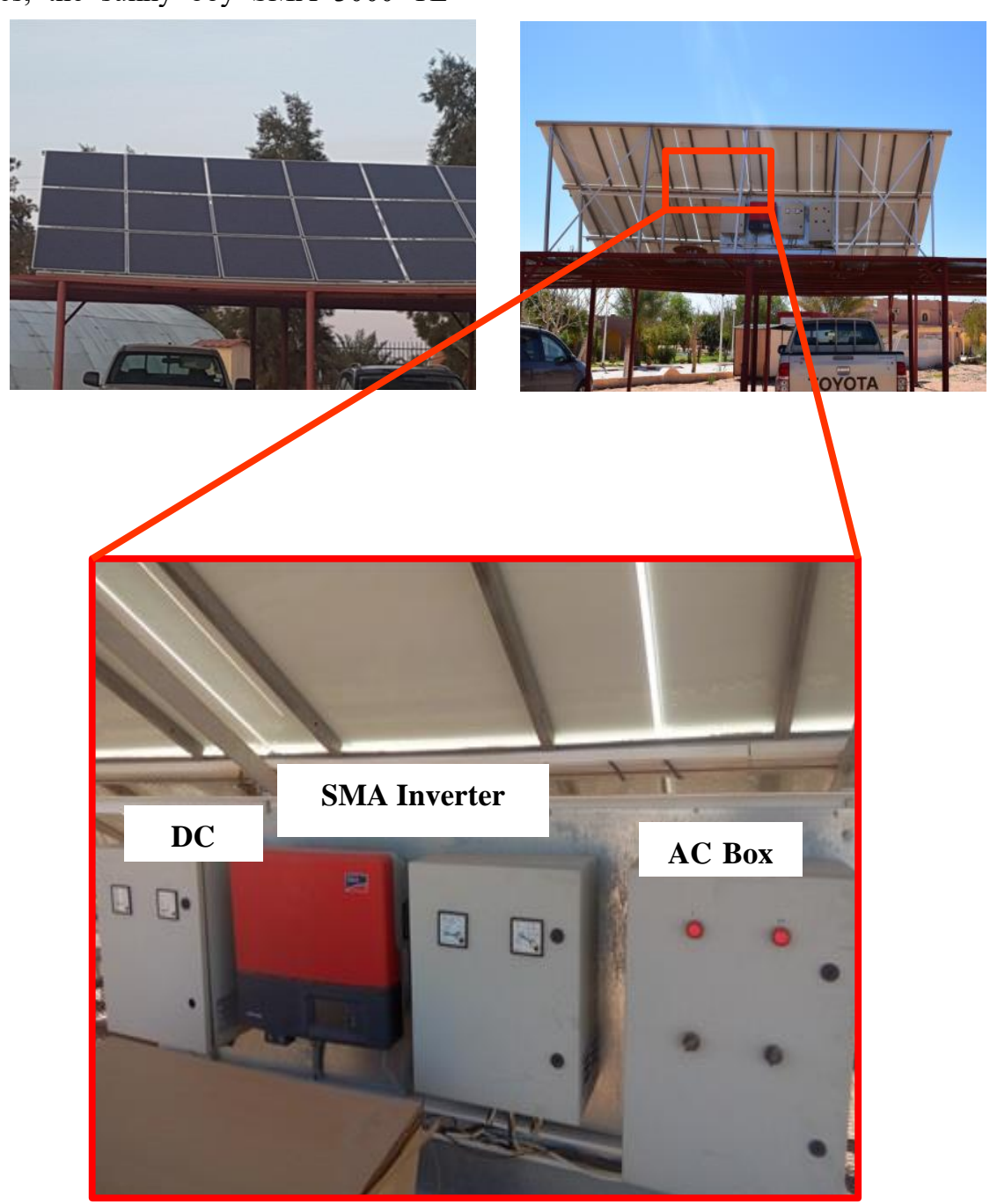

Fig. 5. Mini-photovoltaic power plant fed into the internal electrical grid of the URAER unit 


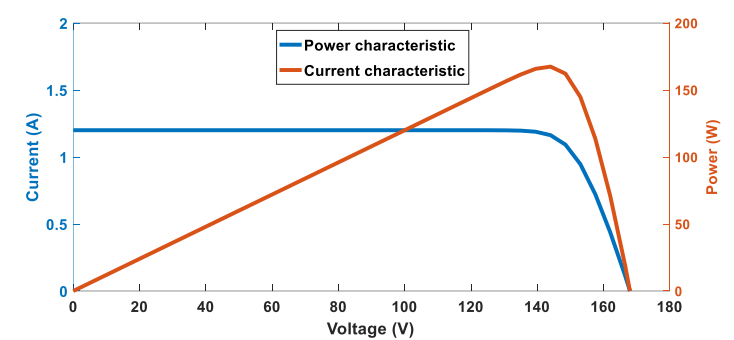

Fig. 6. Current-voltage and power-voltage characteristics of the PV module. Type: Inventux X3 - 125

Characteristics of the X3-125 electrical PV modules and electrical properties of the Sunny Boy SB 3000TL-20 inverter are presented in table 1.

Table 1. Specification of the installed PV module X3-125 and the eelectrical proprieties of the inverter sunny Boy SB

\begin{tabular}{|l|l|l|l|}
\hline \multicolumn{3}{|c|}{$\begin{array}{c}\text { PV Module : Thin Film } \\
\text { Inventux Solar technologies }\end{array}$} & \multicolumn{2}{c|}{ SB 3000TL-20 } \\
\hline Type & $\begin{array}{l}\text { X3- } \\
125\end{array}$ & Max DC power & $3200 \mathrm{~W}$ \\
\hline $\begin{array}{l}\text { Typical maximum } \\
\text { power }\end{array}$ & 127 & Max DC voltage & $550 \mathrm{~V}$ \\
\hline $\begin{array}{l}\text { Voltage at maximum } \\
\text { power (Vmp) }\end{array}$ & $127 \mathrm{~V}$ & $\begin{array}{l}\text { PV voltage range, } \\
\text { MPPT (UPV, max) }\end{array}$ & $\begin{array}{l}125 \mathrm{~V}- \\
440 \mathrm{~V}\end{array}$ \\
\hline $\begin{array}{l}\text { Current at maximum } \\
\text { power (Imp) }\end{array}$ & 1.01 & $\begin{array}{l}\text { Recommended range at } \\
\text { nominal power }\end{array}$ & $188 \mathrm{~V}-$ \\
\hline $\begin{array}{l}\text { Short-circuit current } \\
\text { (Isc) }\end{array}$ & 1.22 & $\begin{array}{l}\text { Max input current (IPV, } \\
\text { max) }\end{array}$ & $170 \mathrm{~A}$ \\
\hline $\begin{array}{l}\text { Open-circuit voltage } \\
\text { (Voc) }\end{array}$ & $\mathrm{A}$ & $\begin{array}{l}\text { Number of MPP } \\
\text { trackers }\end{array}$ & 1 \\
\hline
\end{tabular}

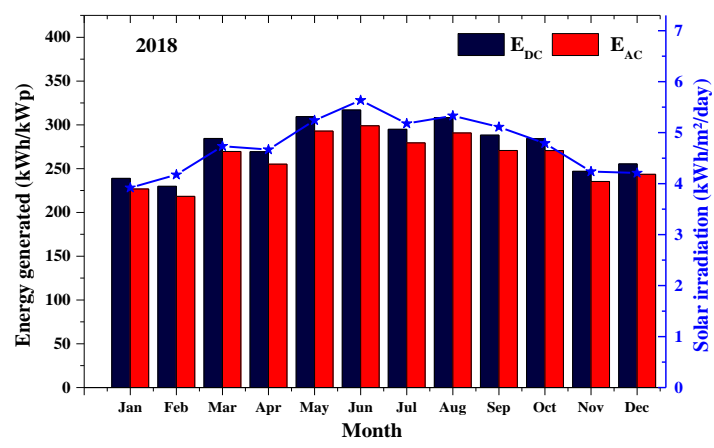

Fig. 7. Variation of monthly energy production DC and $\mathrm{AC}$ of the PV system (2018)

Figure 7 shows the measurements data of total DC and AC energy produced per month for the one year $2018(\mathrm{kWh})$ by the first $2.25 \mathrm{kWp}$ fixed minipower plant. It can be observed that the DC energy produced by the PV array varied between 229,86 $\mathrm{kWh} / \mathrm{kWp}$ in February and 317, $0074 \mathrm{kWh} / \mathrm{kWp}$ in June, while monthly AC energy generated by the inverter which directly fed the internal grid varied between 218,367 kWh in February and 298,938 kWh in June. The total DC energy produced by the PV array over the year 2018 is $3327,159 \mathrm{kWh}(3,327$ MWh) while the total AC energy feeding directly to the local grid is $3152,309 \mathrm{kWh}(3,152 \mathrm{MWh})$.

\subsubsection{Second mini-photovoltaic power plant} with dual axis tracking

The grid-connected field consists of 15 polycrystalline silicon solar modules $150 \mathrm{Wp}$ (Table 2) each one overall installed capacity of $2.25 \mathrm{kWp}$, covering a total surface area of $30 \mathrm{~m}^{2}$ and with dualaxis tracking to increase the energy production (power gain) of the mini-power plant about $45 \%$ compared to fixed structures. This power plant was inaugurated in 19/05/2016. The PV modules are arranged in series and connected to a 3000 W Sunny Boy SB3000 HF inverter (Table 2) feeding directly into internal the grid of the URAER unit (see Fig. 8). Its efficiency is $96 \%$ in the bad case conditions. At the outlet of the inverter, there is a single-phase alternating voltage of $230 \mathrm{~V}, 50 \mathrm{~Hz}$ and at the front, there is a display to read out the DC/AC voltage, the DC/AC current and the DC/AC output power, daily and total amounts of electrical energy generated by the solar PV modules (see Fig. 8). Table 1 shows the specifications of the PV module and the inverter.

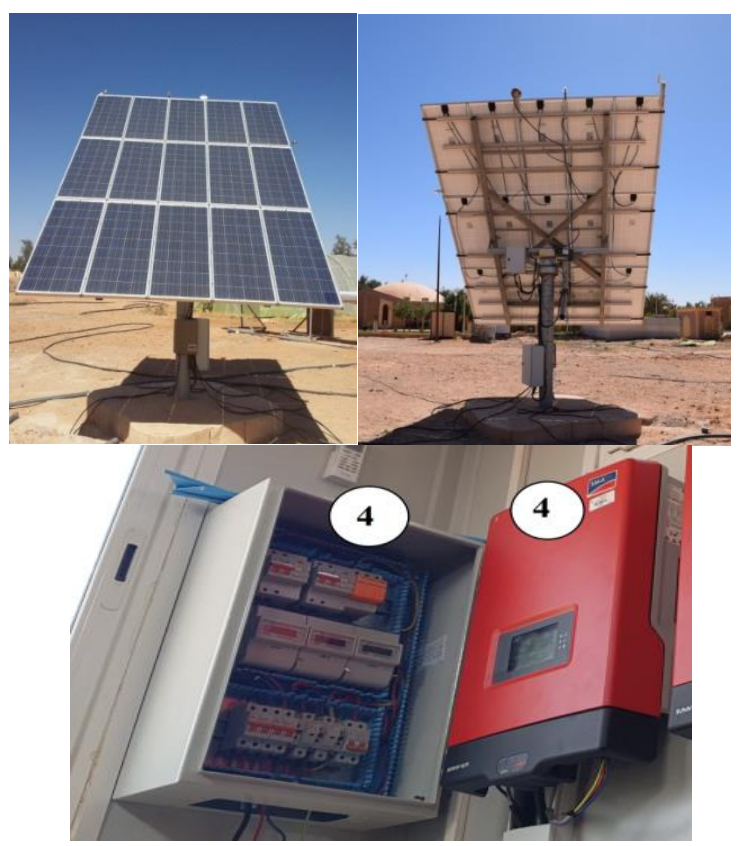

Fig. 8. Mini-photovoltaic power plant with dual axis sun tracking $(2.25 \mathrm{kWp})$ fed into the internal electrical grid, installed at the URAER unit

Fig. 9 shows the PV-array energy output is 12,95 $\mathrm{kWh}$, with peak production of almost 1700 watts, for a cloudy day (09/08/2018). It can be seen that the power production profile is disrupted due to the passage of a cloud which subsequently leading to decreased power production.

Fig.10 shows the PV-array power output for a sunny day (28/09/2019). As in the previous case, the power follows the instantaneous changes in the irradiance. The PV-array energy output is 18,376 $\mathrm{kWh}$. The electrical power output is constant along the day and reaches the maximum about $1848 \mathrm{kWh}$ due to dual-axis sun tracking system operation. We note according to Figure 10 that the electrical energy 
delivered by a fixed module is practically low compared to that of a motorized module. In the case of the fixed PV module, our curve is far from the real curve in the morning and the evening, but the values get closer when we tend towards noon see Figure 10. This divergence explains the need to orient panels towards the sun along the day to have maximum power for each moment of the day.

Table 2 Electrical PV module characteristics Sunmodule 150 and electrical proprieties of the inverter sunny Boy SB

\begin{tabular}{|l|l|l|l|l|}
\hline Parameters & \multicolumn{1}{|c|}{$\begin{array}{c}\text { PV } \\
\text { Module }\end{array}$} & PV array & \multicolumn{3}{|c|}{ SB 3000 HF } \\
\hline Type & Sunmodule & Sunmodule & Max DC power & $3150 \mathrm{~W}$ \\
\hline $\begin{array}{l}\text { Typical } \\
\text { maximum } \\
\text { power }\end{array}$ & $150 \mathrm{Wp}$ & $2250 \mathrm{kWp}$ & $\begin{array}{l}\text { Max DC } \\
\text { voltage }\end{array}$ & $700 \mathrm{~V}$ \\
\hline $\begin{array}{l}\text { Voltage at } \\
\text { maximum } \\
\text { power (Vmp) }\end{array}$ & $18.3 \mathrm{~V}$ & $274.5 \mathrm{~V}$ & $\begin{array}{l}\text { PV voltage } \\
\text { range, MPPT } \\
\text { (UPV, max) }\end{array}$ & $\begin{array}{l}210 \mathrm{~V} \\
-\end{array}$ \\
\hline $\begin{array}{l}\text { Current at } \\
\text { maximum } \\
\text { power (Imp) }\end{array}$ & $8.27 \mathrm{~A}$ & $8.27 \mathrm{~A}$ & $\begin{array}{l}\text { Recommended } \\
\text { range at } \\
\text { nominal power }\end{array}$ & $530 \mathrm{~V}$ \\
\hline $\begin{array}{l}\text { Short-circuit } \\
\text { current (Isc) }\end{array}$ & $8.81 \mathrm{~A}$ & $8.81 \mathrm{~A}$ & $\begin{array}{l}\text { Max input } \\
\text { current (IPV, } \\
\text { max) }\end{array}$ & $15 \mathrm{~A}$ \\
\hline $\begin{array}{l}\text { Open-circuit } \\
\text { voltage } \\
\text { (Voc) }\end{array}$ & $22.5 \mathrm{~V}$ & $337.5 \mathrm{~V}$ & $\begin{array}{l}\text { Number of } \\
\text { MPP trackers }\end{array}$ & $1 / 2$ \\
\hline $\begin{array}{l}\text { Rendement } \eta \\
\text { now }\end{array}$ & $14,3 \%$ & 15 & $\begin{array}{l}\text { Nominale } \\
\text { power AC (230 } \\
\text { V, 50 Hz) }\end{array}$ & $\begin{array}{l}\text { Efficiency } \\
\mathrm{W}\end{array}$ \\
\hline $\begin{array}{l}\text { Number of } \\
\text { module in } \\
\text { series (Ns) }\end{array}$ & 1 & & $96,3 \%$ \\
\hline
\end{tabular}

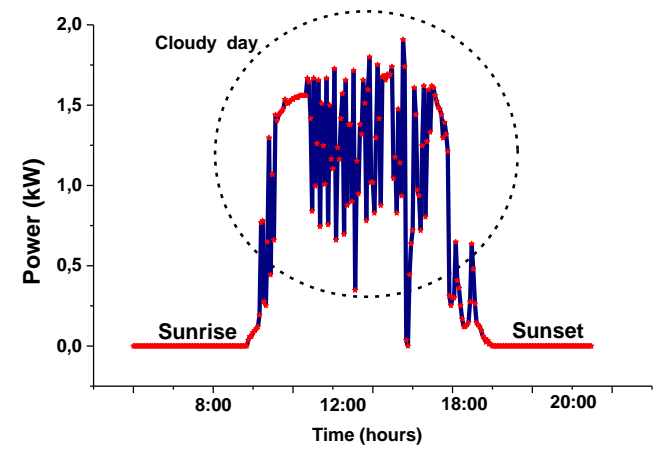

Fig. 9. Daily PV power production profile on a cloudy day $(09 / 08 / 2018)$

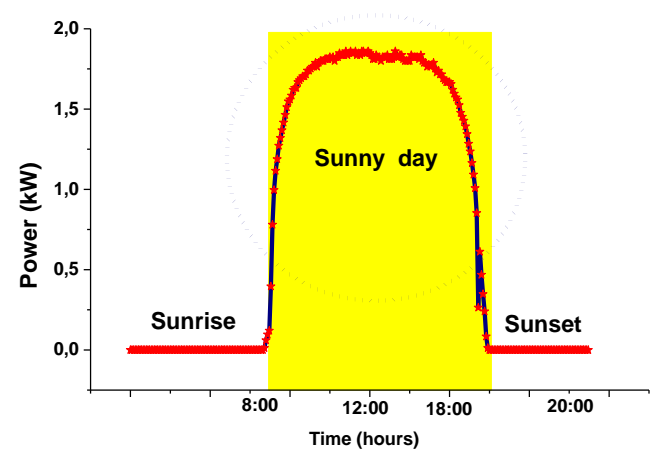

Fig. 10. Daily PV power production profile on a sunny day $(28 / 09 / 2019)$

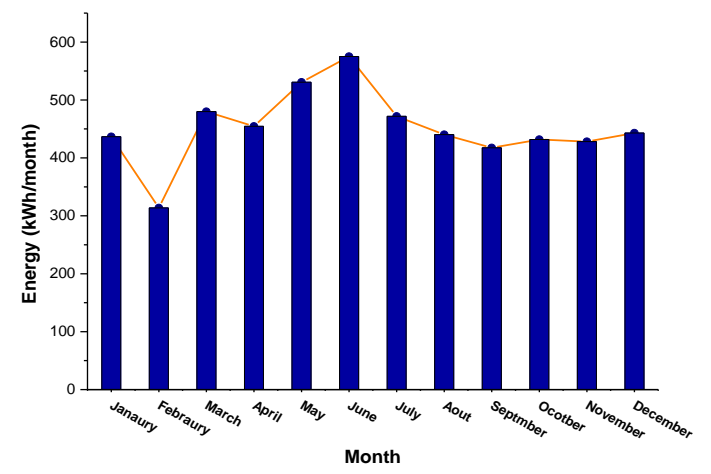

Fig. 11. The energy produced per month for the year 2019

Fig. 11 shows the monthly total energy generated and feeding directly to the local grid by the power system during the monitored period the monitored data of the plant form $1^{\text {st }}$ January, to December, 31 ,2019 varied between 313,629 kWh/kWp in February and $575,117 \mathrm{kWh} / \mathrm{kWp}$ in June. The total energy over the year 2019 is $5423,174 \mathrm{kWh}(5,423 \mathrm{MWh})$.

\subsubsection{Third mini-photovoltaic power plant with dual axis tracking}

The 11.28kWp photovoltaic system connected to the network ensures the total injection of the energy produced in the internal grid of the applied research unit for renewable energies (URAER). This power plant was commissioned in November 2017. It consists of 3 mini-power plants of $3.76 \mathrm{kWp}$ equipped with a sun tracking system to increase their energy efficiency compared to the same fixed-tilt system. Each mini-power plants connected to one of the three phases of the unit's internal network through a single inverter sunny boy 4000 TL (Table $3)$. Each mini-central is equipped with 16 monocrystalline silicon modules $235 \mathrm{Wp} 24 \mathrm{~V} 9$ A, "CentroSolar S-Class Professional", with a total surface area of $30 \mathrm{~m}^{2}$. Fig. 12-14 shows the gridconnected PV system configuration.

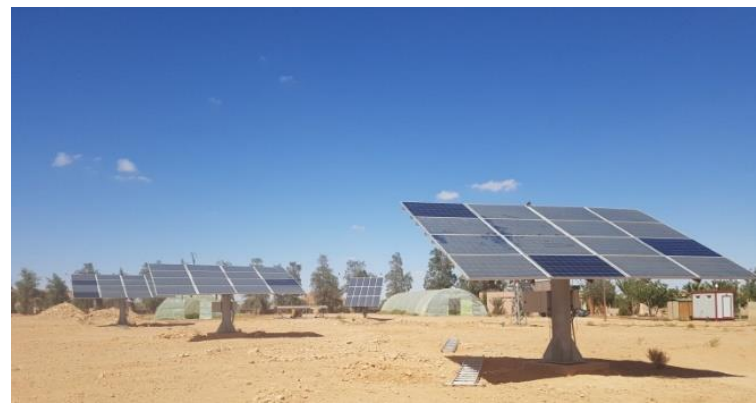

Fig. 12. Photovoltaic mini-power plant with solar tracking system $(11.28 \mathrm{kWp})$ connected to the internal network of the URAER unit

The electrical characteristics of an S 235P60 Professional polycrystalline module array and the inverter sunny Boy SB $4000 \mathrm{TL}$ is presented in the following table. 

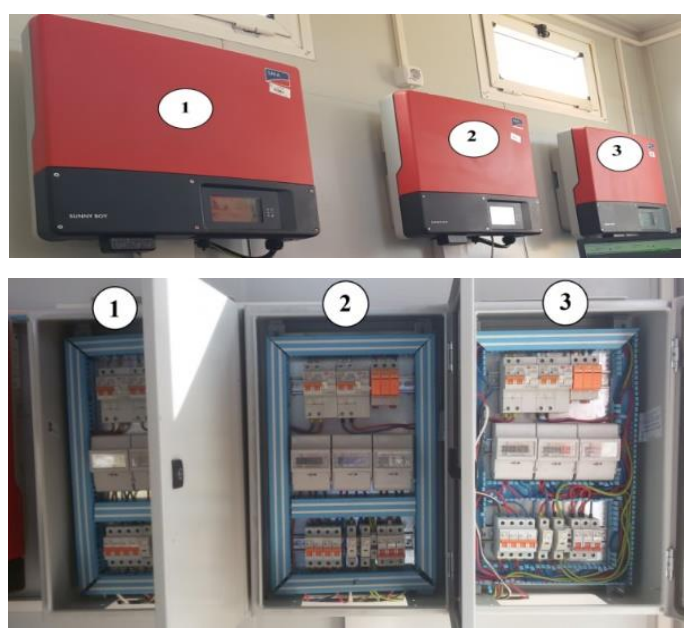

Fig. 13. Inverters and injection cabinets

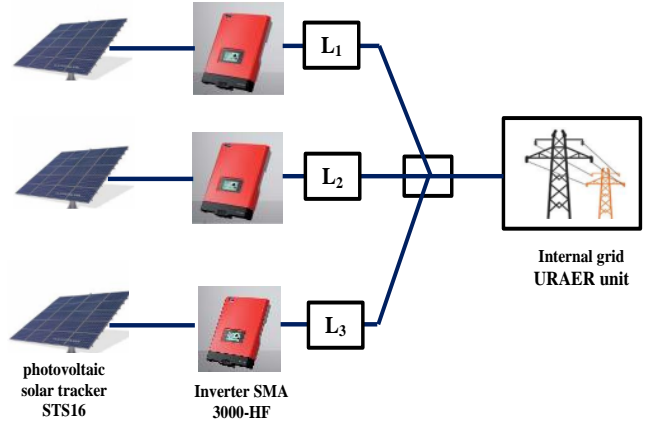

Fig. 14. Synoptic diagram of the three PV power plants dual axis solar tracking with connected to the local grid

Table 3. Electrical PV module characteristics CentroSola S 235P60 and electrical proprieties of the inverter sunny Boy

\begin{tabular}{|c|c|c|c|c|}
\hline Parameters & PV & PV & \multicolumn{2}{|c|}{ SB 4000TL } \\
\hline Type & $\begin{array}{l}\text { CentroS } \\
\text { olar }\end{array}$ & $\begin{array}{l}\text { CentroS } \\
\text { olar }\end{array}$ & $\begin{array}{ll}\text { Max } & \text { DC } \\
\text { power } & \\
\end{array}$ & $\begin{array}{l}4200 \\
W \\
\end{array}$ \\
\hline $\begin{array}{l}\text { Typical } \\
\text { maximum } \\
\text { power }\end{array}$ & $235 \mathrm{Wp}$ & 3513.51 & $\begin{array}{ll}\text { Max } & \text { DC } \\
\text { voltage } & \end{array}$ & $550 \mathrm{~V}$ \\
\hline $\begin{array}{l}\text { Voltage at } \\
\text { maximum } \\
\text { power }(\mathrm{Vmp})\end{array}$ & $\begin{array}{l}28,70 \\
V\end{array}$ & 429 & $\begin{array}{l}\text { PV voltage } \\
\text { range, MPPT } \\
(\mathrm{UPV}, \max )\end{array}$ & $\begin{array}{l}175 \mathrm{~V} \\
-440 \\
\mathrm{~V} \\
\end{array}$ \\
\hline $\begin{array}{l}\text { Current at } \\
\text { maximum } \\
\text { power (Imp) }\end{array}$ & $8,19 \mathrm{~A}$ & 8.19 & $\begin{array}{l}\text { Recommended } \\
\text { range at } \\
\text { nominal power }\end{array}$ & $400 \mathrm{~V}$ \\
\hline $\begin{array}{l}\text { Short-circuit } \\
\text { current (Isc) }\end{array}$ & $8,59 \mathrm{~A}$ & 8.59 & $\begin{array}{ll}\begin{array}{l}\text { Max } \\
\text { current }\end{array} & \text { input } \\
\text { max) } & \\
\end{array}$ & $15 \mathrm{~A}$ \\
\hline $\begin{array}{l}\text { Open-circuit } \\
\text { voltage (Voc) }\end{array}$ & $36,46 \mathrm{~V}$ & 546.9 & $\begin{array}{l}\text { Number of } \\
\text { MPP trackers }\end{array}$ & $1 / 2$ \\
\hline Rendement $\eta$ & $14,3 \%$ & & $\begin{array}{l}\text { Nominale } \\
\text { power AC } \\
(230 \mathrm{~V}, 50 \mathrm{~Hz}) \\
\end{array}$ & $\begin{array}{l}4000 \\
W\end{array}$ \\
\hline $\begin{array}{ll}\text { Number of } \\
\text { module in } \\
\text { series (Ns) }\end{array}$ & 1 & 16 & Efficiency & $97 \%$ \\
\hline
\end{tabular}

\section{Radiation effect on the characteristic of the photovoltaic field}

Fig. 15 presents the evolution of the characteristic $(\mathrm{I}-\mathrm{V})$ and $(\mathrm{P}-\mathrm{V})$ of the PV field (16 modules in series) as a function of the irradiation. a)

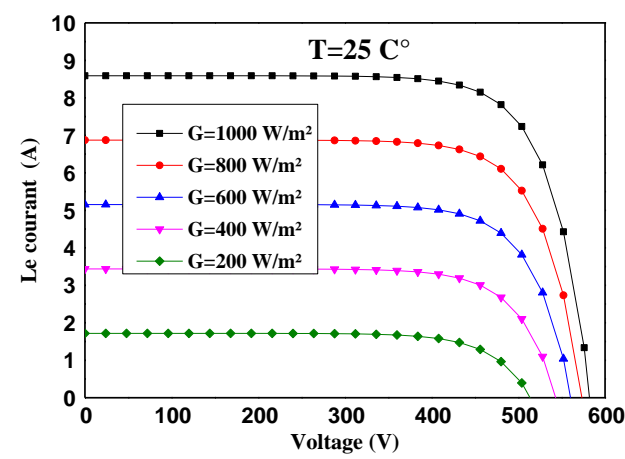

b)

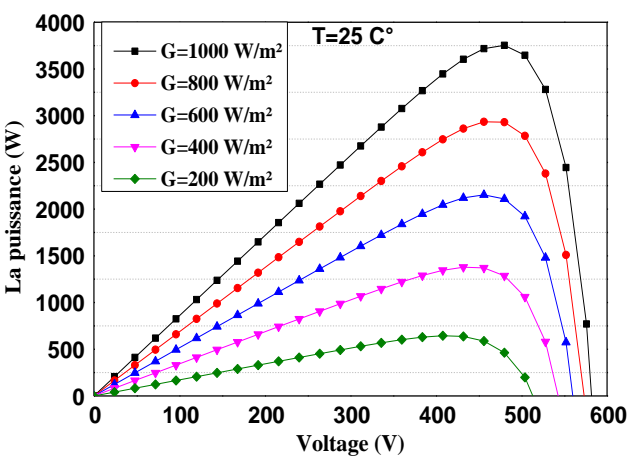

Fig. 15. Effect of irradiation on the I-V and P-V characteristic of the photovoltaic field (16 modules in series)

\section{Effect of temperature on the characteristic of the photovoltaic field}

Fig. 16 shows the evolution of the characteristic $(\mathrm{I}-\mathrm{V})$ and $(\mathrm{P}-\mathrm{V})$ of the PV field (16 modules in series) as a function of temperature.

a)

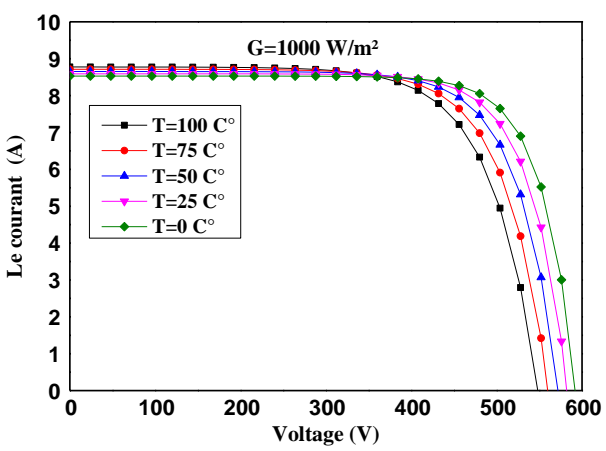

b)

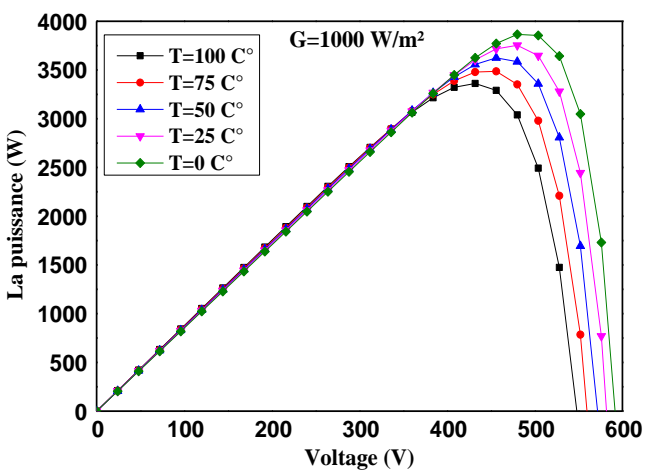

Fig. 16. Effect of temperature on the I-V and P-V characteristic of the photovoltaic field (16 modules in series) as a function of temperature. 


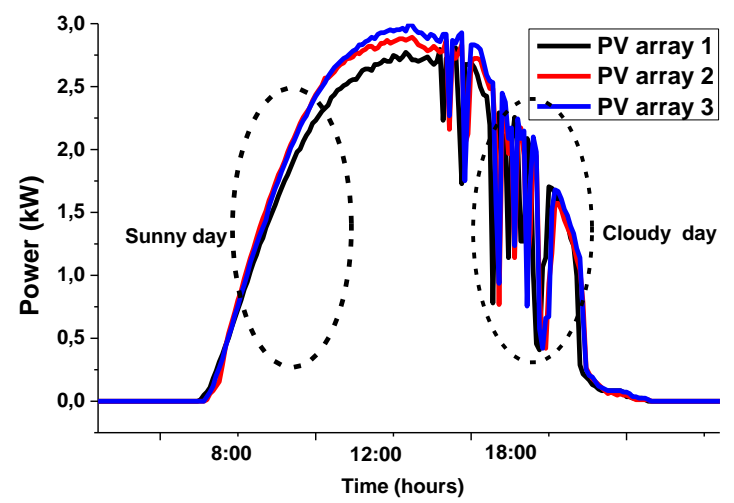

Fig. 17. Daily PV power production profile on a partly cloudy day (September 21, 2018)

Fig. 17 presents the daily electric power of the photovoltaic field (September 21, 2018, clear sky). The power gradually increases from sunrise until 3 $\mathrm{kWp}$ at noon, while from noon until sunset the sky is cloudy and the power decreases and becomes zero at night. The total produced energy by the PV array was $19,392 \mathrm{kWh}$

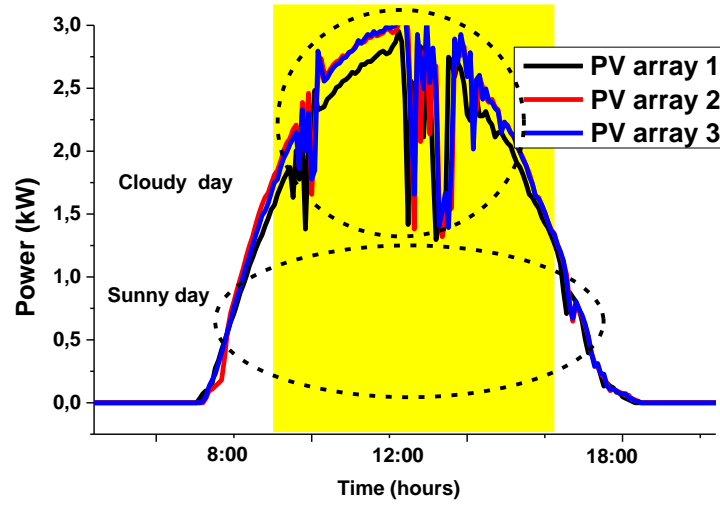

Fig. 18. Daily PV power production profile on a partly cloudy day (June 26, 2018)

Fig. 18 shows the daily electric power produced by the photovoltaic field (June 26, 2018, cloudy sky). As we can see that in the morning and evening the sky is sunny, but in the middle of the day the sky is cloudy (from 11h: 00 to $15 \mathrm{~h}: 00$ ) and the power reached its maximum. The total produced energy by the PV array was $19,111 \mathrm{kWh}$.

Fig. 19 shows the daily PV power production profile on a full sunny day (October 25, 2018). It varies during the day in a Gaussian way between 0 $\mathrm{W} / \mathrm{m}^{2}$ and $3000 \mathrm{~W}$. PV power production is weak in the vicinity of sunrise and sunset, and it reaches the maximum in the middle of the day, that is to say at noon when the sun's height is maximum. The total produced energy by the PV array was $21,553 \mathrm{kWh}$.

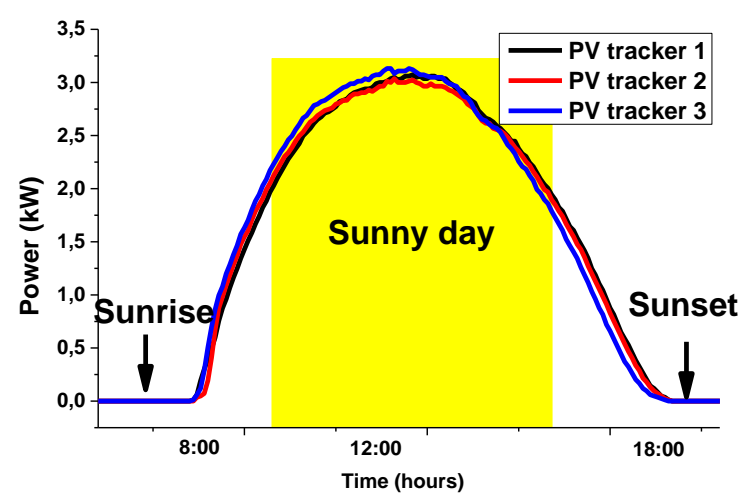

Fig. 19. Daily PV power production profile on a sunny day (October 25, 2018)

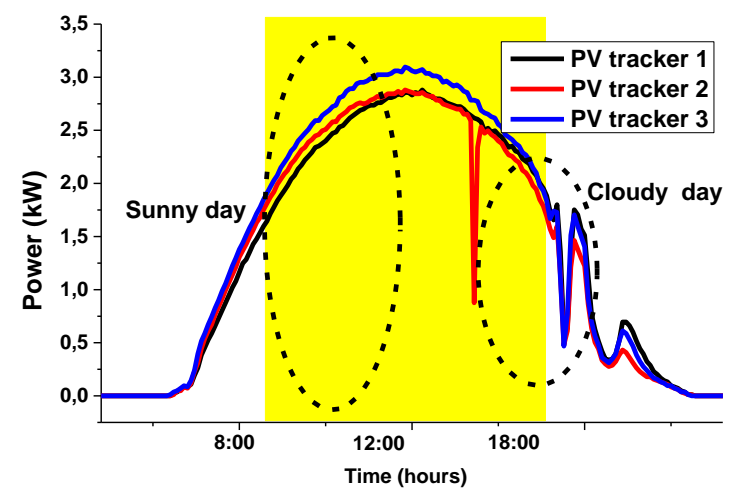

Fig. 20. Daily PV power production profile on a mostly sunny day (August 31, 2018)

Fig. 20 depicts the daily PV power production profile on a mostly sunny day (August 31,2018 ). The total produced energy by the PV array was 20,834 kWh.

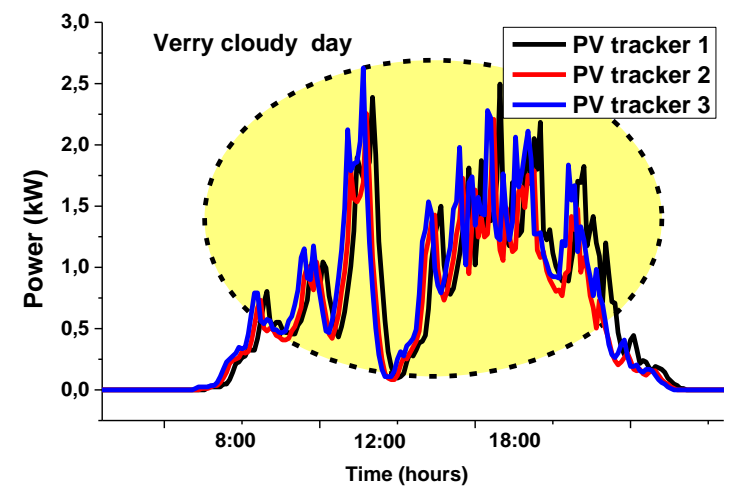

Fig. 21. Daily PV power production profile in an overcast day (August 12, 2018)

Fig. 21 presents the daily PV power production profile on an overcast day (August 12, 2018). The total produced energy by the PV array was 10,722 $\mathrm{kWh}$. the electrical output is in harmony with the solar radiation that receives each PV panel.

\section{RESULTS AND DISCUSSIONS}

Operational performance of the all present ongrid solar PV system installed analyzed for the actual 
recorded output real data of the plants and weather parameters.

The output daily power profile of the all PV plant $(\mathrm{kW})$ is shown in Fig 22. The total produced energy by the PV array on 07 October 2019 was 79,662 $\mathrm{kWh}$ while the total produced energy by the PV array on 30 September 2019 was 75,975 kWh. From all results above, we can see that all PV array have lower conversion efficiency compared to their nominal value (power losses). The PV panels under continuous operation eventually suffer from obstacles. Among the obstacles that impede these power plants in this site (arid and semi-arid area) are sand storms and the accumulation of sand, dirt, and dust on the solar panels which decrease the irradiance transmittance that caused the degradation in the electrical performance and reduction of PV power output (see Fig 23). The soiling losses were $4-5 \%$ during the winter and $6-7 \%$ during the summer period, resulting in annual losses at 5.86\% [9]. To maximize the production of photovoltaic solar modules and minimize degradation due to the accumulation of dust, frequent cleaning is strongly recommended. Another phenomenon (most important factors) can be observed that the most time operation temperature of the power plants was higher than $25^{\circ} \mathrm{C}$, which contributes to the reduction in output power.

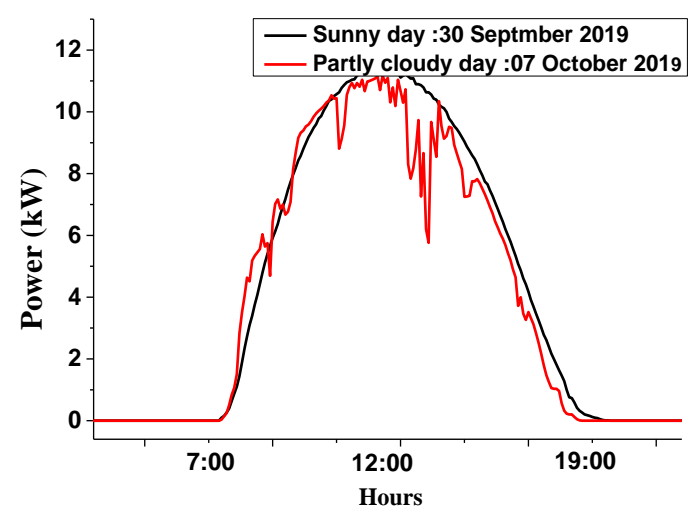

Fig. 22. daily Output power profile of the all PV plant (kW) for two days: partly cloudy day (07 Oct 2019) and sunny day (30 Sep 2019)

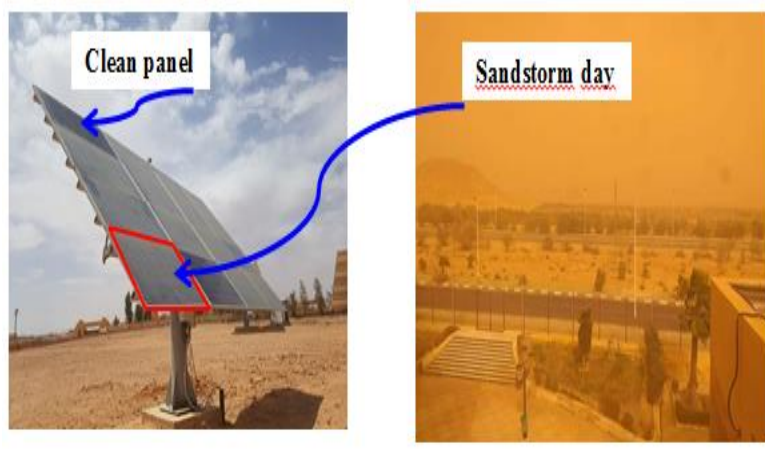

Fig. 23. picture demonstrate the influence of sandstorms on PV array

Fig. 24 shows the daily energy generated by all this installation in two months, July and October. As we can observe that in October the daily electricity generated by the all power plant varied between 64 KWh and $94 \mathrm{kWh}$, while in July, the daily electricity generated by the all power plant varied between 71 $\mathrm{kWh}$ and $91 \mathrm{kWh}$. The total energy generated by the installation in October $2566 \mathrm{kWh}(2,566 \mathrm{MWh})$ while, the total energy generated by the installation in July $2658 \mathrm{kWh}(2,658 \mathrm{MWh})$.

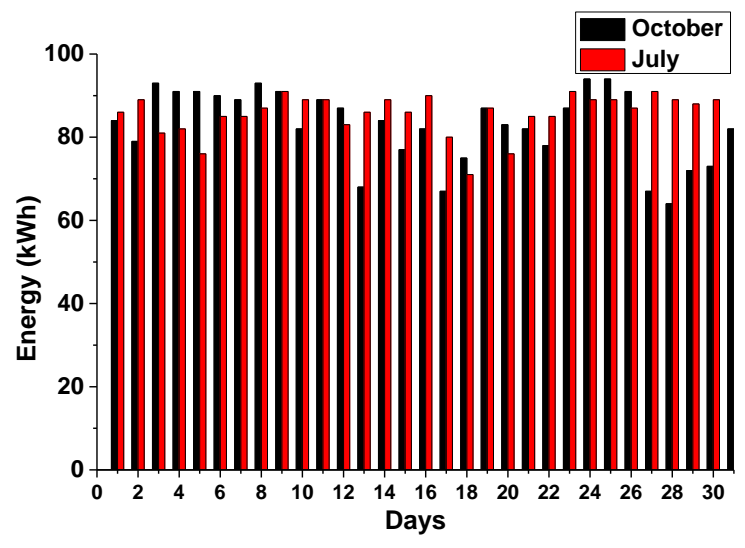

Fig. 24. Daily energy generated by all PV power plants $(\mathrm{kWh})$ in July and October

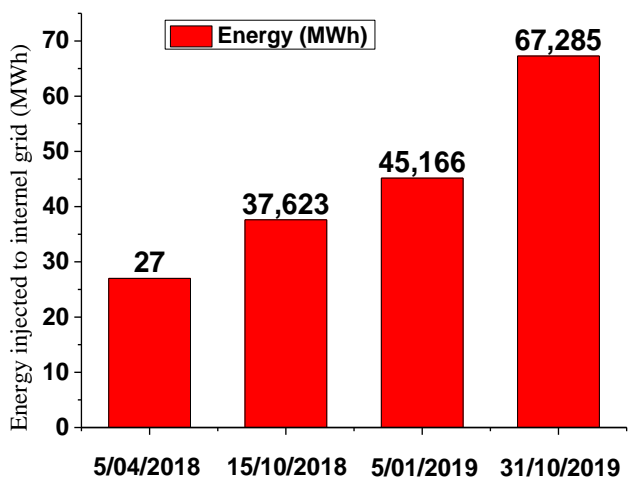

Fig. 25. The gradual incremental production of energy injected into the internal grid

Fig. 25 shows the gradual incremental production of energy injected into the internal grid .As shown in figure, the total energy fed to the internal grid has grown from $27 \mathrm{MWh}$ in $05 / 04 / 2018$ to a maximum of 67.28 MWh recorded in 31/10/2019.

- The energy injected into the internal network of the URAER unit by all the photovoltaic power plants since their commissioning until the day $05 / 04 / 2018$ is $27 \mathrm{MWh}$.

- The energy injected by all the photovoltaic power plants since their commissioning until the day $15 / 10 / 2018$ is $37.62 \mathrm{MWh}$.

- The energy injected by all the photovoltaic power plants since their commissioning until the day $05 / 01 / 2019$ is $45.16 \mathrm{MWh}$.

- The energy injected by all the photovoltaic power plants since their commissioning until the day $31 / 04 / 2019$ is $67.28 \mathrm{MWh}$.

The monthly production of all PV plants $(\mathrm{kWh})$ during the year 2019 is shown in Fig. 26. The 
production was considered high in the summer months (July-August) due to high solar irradiation resources. However, production in winter very limited, particularly in January and February. We can observe that the energy generated by all power plants, especially in the summer months reaches the highest values in July $(2655,981 \mathrm{kWh})$. Whereas it is lower in the winter months, especially in January $(1623,314 \mathrm{kWh}$ ). Within the reporting period (from $1^{\text {st }}$ January 2019 to last august 2019), the three power plants delivered $17422,252 \mathrm{kWh}(17,422 \mathrm{MWh})$ of electricity to the internal grid.

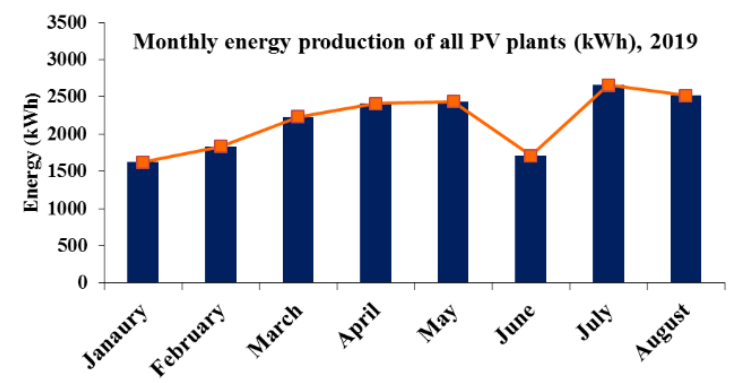

Fig. 26. Monthly energy produced by all PV plants from 1st January 2019 to last august $2019(\mathrm{kWh})$

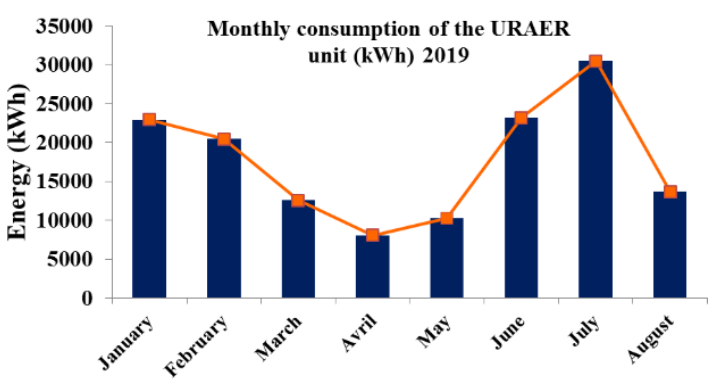

Fig. 27. Monthly energy consumed by the URAER Unit from 1st January 2019 to last august 2019 (kWh)

The monthly consumption of the URAER unit (kWh) during the year 2019 is shown in Fig. 27. Generally, consumption varies depending on the type of load and equipment used, according to the times and by season. The electricity consumption of the URAER unit, reaches the highest values especially in the winter and summer months. The reason is due to the operation of air conditioners and heating in this period (summer and winter), which requires significant energy; whereas it is lower in August due to the summer holiday.

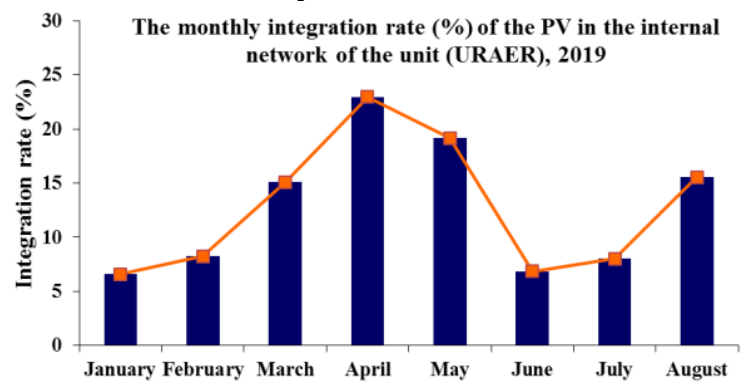

Fig. 28. The monthly integration rate (\%) of the PV in the internal network of the URAER, from 1st January 2019 to last august 2019
The monthly integration rate (\%) of the PV in the internal network of the URAER during the year 2019 is shown in Fig. 28. As we can see that the rate of integration of solar energy by all PV arrays in the internal network of the URAER varied between 6 , $60 \%$ in January and $22,96 \%$ in April. .The integration of this renewable energy generation into the transmission network in URAER during considered satisfactory in 2019.

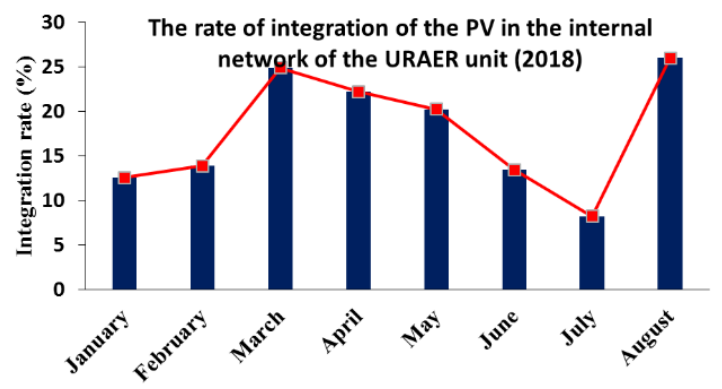

Fig. 29. The monthly integration rate (\%) of the PV in the internal network of the URAER, from 1st January 2018 to last august 2018

The monthly integration rate (\%) of the PV in the internal network of the URAER during the year 2018 is depicted in Fig. 29. As we can see that the rate of integration of solar energy by all PV arrays in the internal network of the URAER varied between 8 , $20 \%$ in July and $25,96 \%$ in August .The integration of this renewable energy generation into the transmission network in URAER during considered satisfactory in 2018. All results obtained above are summarized in table 4.

Table 4. All system PV production URAER unit consumption and integration rate (\%) of the PV in the

\begin{tabular}{|l|l|l|l|}
\hline & $\begin{array}{l}\text { All system } \\
\text { PV } \\
\text { production }\end{array}$ & $\begin{array}{l}\text { URAER unit } \\
\text { consumption }\end{array}$ & $\begin{array}{l}\text { Rate } \\
\text { integration } \\
(\%)\end{array}$ \\
\hline January & 1623,314 & 24568,314 & 6,61 \\
\hline February & 1834,244 & 22276,244 & 8,23 \\
\hline Mars & 2232,58 & 14787,58 & 15,10 \\
\hline April & 2409,738 & 10492,738 & 22,97 \\
\hline May & 2439,539 & 12735,539 & 19,16 \\
\hline June & 1707,416 & 24922,416 & 6,85 \\
\hline July & 2655,981 & 33117,981 & 8,02 \\
\hline August & 2519,44 & 16193,44 & 15,56 \\
\hline Tolal & 17422,252 & 159094,252 & 10,95 \\
\hline
\end{tabular}

\section{ECONOMICAL STUDY}

In the Algerian official journal number 23 (23 April 2014), the selling price of energy is expressed at 15,94 Algerian dinars/kWh (0.12 euro/kWh) for many hours more than 1725 hours where the electricity purchase price is stabilized by the Algerian government and the price is 4,179 Algerian dinars $/ \mathrm{kWh}(0,03$ euro $/ \mathrm{kWh})$ [26]. From the first January to last august 2019 , the energy consumption 
of out unit URAER CDER is 159.094 MWh. The energy production of all PV plants is $17.422 \mathrm{MWh}$.

Fig. 30 shows the energy produced by solar plants and consumed by the URAER unit. It can be seen that the total produced energy by all PV arrays was 171.422 MWh which supplied to the internal grid and while, the consumed energy by the URAER unit was $159,094 \mathrm{kWh}$. Approximately 10, $95 \%$ of the 159,094 MWh energy consumed in the whole year is provided from the generated PV solar energy that is $17,422 \mathrm{MWh}$.

Table 5 . The electricity bill sold and purchased by UEAER

\begin{tabular}{|l|l|l|l|l|}
\hline $\begin{array}{l}1 \text { st January } \\
\text { to } 31\end{array}$ & $\begin{array}{l}\text { Energy } \\
\text { (MWh) }\end{array}$ & $\begin{array}{l}\text { Unitary } \\
\text { price } \\
\text { Eugust } \\
2019\end{array}$ & $\begin{array}{l}\text { Total } \\
\text { price } \\
\text { (DA/ } / \mathrm{kWh})\end{array}$ & $\begin{array}{l}\text { Total price } \\
\text { (Algerian } \\
\text { dinars) }\end{array}$ \\
\hline Production & 17.422 & $\begin{array}{l}0.12 \\
(15,94)\end{array}$ & 2090,64 & 277706,68 \\
\hline $\begin{array}{l}\text { Consumpti } \\
\text { on }\end{array}$ & 159.09 & $\begin{array}{l}0.03 \\
(4,179)\end{array}$ & 4772,82 & 664853,826 \\
\hline
\end{tabular}

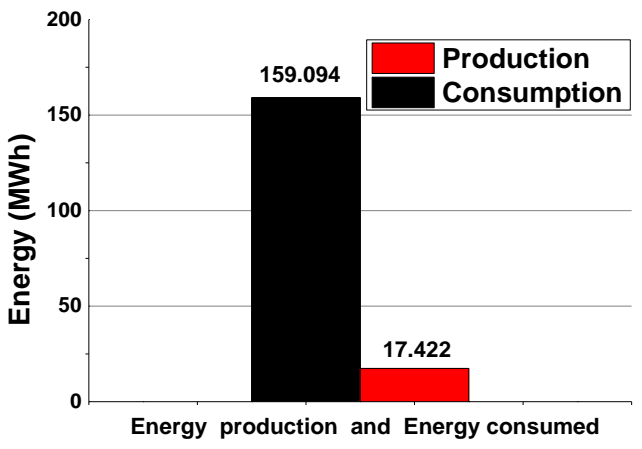

Fig. 30. Energy produced by solar plants and consumed by the URAER unit
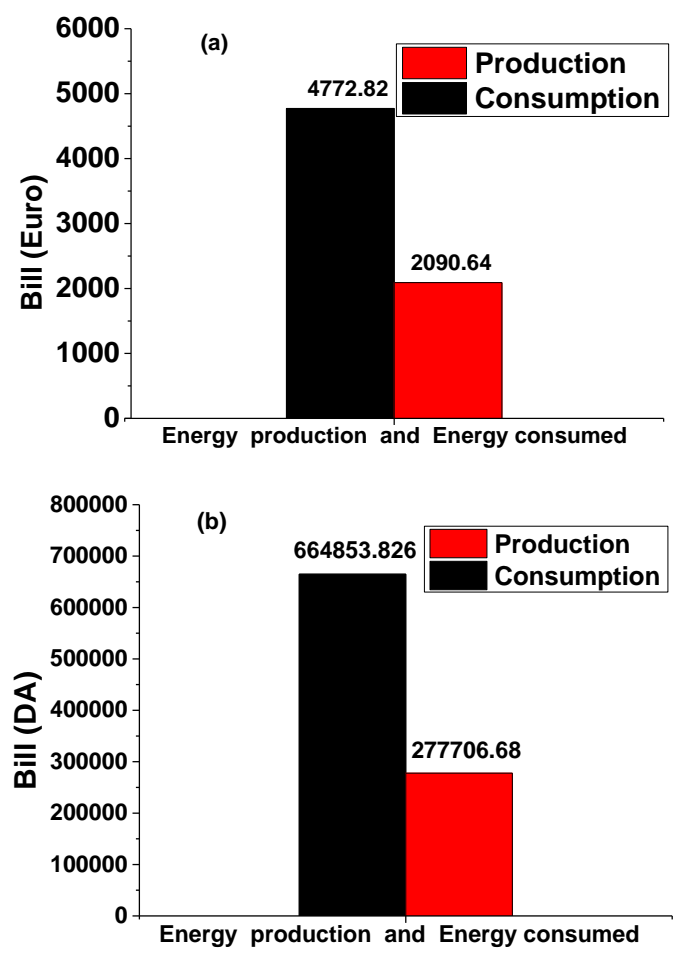

Fig. 31. The electricity bill sold and purchased by UEAER unit a) with Euro b) with Algerian dinars
Fig. 31 shows the electricity bill sold and purchased by the UEAER unit with Euro and with Algerian dinars. The cost of electrical energy produced by solar plants is 2090,64 euro (277706,68 Algerian dinars) while the cost of energy consumed by the Applied Research Unit in renewable energies is 4772,82 euro (664853, 826 Algerian dinars).

\section{CONCLUSION}

This paper investigates the performance analysis based on experimental measurements of $16.28 \mathrm{kWh}$ photovoltaic grid-connected systems installed in the site of the Applied Research Unit for Renewable Energies (URAER) located at Ghardaia, southern Algeria. The results demonstrate that the Ghardaia region (arid and semi-arid climate) has the great potential of producing electricity through photovoltaic solar energy due to its strategic location. The photovoltaic generators operated better, but some factors this harsh environment drastically disrupts the electric output power which should be taken with some caution such as an increase in cell temperature and the accumulation of dust and sands on the photovoltaic surface, frequent cleaning is strongly recommended. Based on the analysis carried out in this work, the following conclusions are summarized:

- From the first January to last august 2019, the electricity production from the PV system was $17,422 \mathrm{MWh}$ fed into the internal electrical grid of the applied research unit for renewable energies unit (URAER) and the electric energy consumption was 159,094 MWh. These values are satisfactory.

- Photovoltaic panels carried out on dual-axis sun tracking are more efficient in terms of output power (power gain). It allows for increasing the production of energy (power gain) from 30 to $40 \%$ compared to a fixed PV system.

- The exploitation of the energy produced by minipower stations within our unit proves the benefit, energy efficiency and reliability of this type of system.

- The rate of integration of solar energy by all PV arrays in the internal network of the URAER varied between $6,60 \%$ in January and 22, 96\% in April. .The integration of this renewable energy generation into the transmission network in URAER during considered satisfactory in 2019.

- From the first January to last August 2019, the cost of electrical energy produced by solar plants is 2090, 64 euro (277706,68 Algerian dinars) while the cost of energy consumed by the Applied Research Unit in renewable energies is 4772,82 euro (664853, 826 Algerian dinars).

- The total energy fed to the internal grid has grown from $27 \mathrm{MWh}$ on $05 / 04 / 2018$ to a maximum of $67.28 \mathrm{MWh}$ recorded on $31 / 10 / 2019$. The energy from these continuous 
systems reduces the electricity bills consumed within our unit.

- For high energy production of solar panels, the best weather conditions are required, excellent solar brightness, low temperature, and the solar panels are very clean.

- As a conclusion, the integration of this renewable energy generation with the transmission network is considered satisfactory. Generalization of the application of this type of system and its integration into the conventional electrical network is recommended.

- The presented study would be used to serve as guidelines (a catalog) to guide designers and researchers or implement small applications of grid-connected PV systems and large-scale solar photovoltaic plants especially in countries with a similar climate (arid and semi-arid).

Dust is generally a major concern and constraint that greatly affects the yield of grid-connected PV systems and cannot be neglected in these harsh climates. Therefore, regular cleaning becomes necessary after each period. Another problem facing photovoltaic systems is the terrible rise in temperature, especially in the summer, cooling techniques suggested as one of the solutions .In next future work,techno-economic analysis of a similar photovoltaic power plant is recommended.

\section{ACKNOWLEDGMENT}

I am grateful to the Applied Research Unit on Renewable Energy, URAER, Ghardaia, affiliated to the Renewable Energy Development Center (CDER), Algeria where this work was carried out.

This research is conducted under the financial support of the Directorate General for Scientific Research and Technological Development - Algerian Ministry of Higher Education and Scientific Research.

\section{REFERENCES}

1. REN21 Renewables 2018 Global Status Report. 2018

2. Semaoui S, Abdeladim K, Taghezouit B, Hadj Arab A, Razagui A, Bacha S, Boulahchiche S, Bouacha S, Gherbi A, Experimental investigation of soiling impact on grid connected PV power. Energy Reports. 2020;6:302-308.

3. Bandou F, A. Hadj Arab, MS. Belkaid, PO. Logerais R. Olivier, A. Charki. Evaluation Performance of Photovoltaic Modules after a Long Time Operation in Saharan Environment. International Journal of Hydrogen Energy. 2015;4:13839-13848. https://doi.org/10.1016/j.ijhydene.2015.04.091

4. Bouraiou, A, Hamouda M, Chaker A, Mostefaoui M, Lachtar S, Sadok M, Boutasseta N, Othmani M, Issam A. Analysis and Evaluation of the Impact of Climatic Conditions on the Photovoltaic Modules Performance in the Desert environment. Energy Conversion and Management. 2015;106:1345-1355. https://doi.org/10.1016/i.enconman.2015.10.073.

5. Fezzani A, Hadj Mahammed I, Said D, Zaghba L, Bouchakour A, Benbitour M, Hamid Oudjana S.
Degradation and Performance Evaluation of PV Module in Desert Climate Conditions with Estimate Uncertainty in Measuring. Serbian Journal of Electrical Engineering. 2017;14(2):277-299. https://doi.org/10.2298/sjee1702277f.

6. Mostefaoui M, Ziane A, Bouraiou A, Khelifi S. Effect of sand dust accumulation on photovoltaic performance in the Saharan environment: southern Algeria (Adrar), Environmental Science and Pollution Research. 2019;26:259-268 https://doi.org/10.1007/s11356-018-3496-7

7. Ramadan J, Mustafa Mohamed R. Gomaa, Mujahed Al-Dhaifallah, Hegazy Rezk. Environmental Impacts on the Performance of Solar Photovoltaic Systems, Sustainability. 2020;12:608. https://doi.org/10.3390/su12020608.

8. Makrides G, Zinsser B, Norton M, Georghiou GE, Schubert M, Werner JH. Potential of photovoltaic systems in countries with high solar irradiation. Renewable and Sustainable Energy Reviews 2010;14:754-62.

9. Kymakis E, Kalykakis S, Papazoglou TM. Performance analysis of a grid connected Photovoltaic Park on the island of Crete. Energy Conversion and Management. 2009;50(3):433-438.

10. Hegazy Rezk, Mohamed R. Gomaa, Mohamed A. Mohamed, Mohammed J. Al Shammri. Energy Performance Analysis of On-Grid Solar Photovoltaic System- a Practical Case Study, International Journal of Renewable Energy Research-IJRER. 2019; 9(3).

11. Sharma Vikrant, Kumar Arun, Sastry OS, Chandel SS. Performance assessment of different solar photovoltaic technologies under similar outdoor conditions. Energy. 2013;58:511-518.

12. Mohamed R. Gomaa, Waleed Hammad, Mujahed AlDhaifallah, Hegazy Rezk. Performance enhancement of grid-tied PV system through proposed design cooling techniques: An experimental study and comparative analysis. Solar Energy. 2020;211: 1110 1127. https://doi.org/10.1016/j.solener.2020.10.062.

13. Zaghba L, Khennane M, Fezzani A, Borni A, Hadj Mahammed I. Experimental performance assessment of a $2.25 \mathrm{kWp}$ Rooftop PV system installed in the desert environment: a case study of Ghardaia, Algeria, International Journal of Sustainable Engineering.2020 https://doi.org/10.1080/19397038.2020.1743377.

14. Zaghba L, Khennane M, Fezzani A, Borni A, Hadj Mahammed I. Experimental outdoor performance evaluation of photovoltaic plant in a sahara environment (Algerian Desert). International Journal of Ambient Energy. 2019;1-11. https://doi.org/10.1080/01430750.2019.1636865.

15. Rawat R, Kaushik SC, Lamba Ravita. A review on modeling, design methodology and size optimization of photovoltaic based water pumping, standalone and grid connected system. Renew Sustain Energy Rev 2016;57:1506-19.

16. Ayompe LM, et al., Measured performance of a 1.72 $\mathrm{kW}$ rooftop grid connected photovoltaic system in Ireland. Energy Convers Manage. 2010;52 (2):81625. https://doi.org/10.1016/j.enconman.2010.08.007.

17. Necaibia A et al, Analytical assessment of the outdoor performance and efficiency of grid-tied photovoltaic system under hot dry climate in the south of Algeria, Energyconversion and Management. 2018; 171:778786.

18. Skoplaki E, Palyvos JA. On the temperature dependence of photovoltaic module electrical 
performance: a review of efficiency/power correlations, Sol. Energy. 2009;83:614-624. https://doi.org/10.1016/j.solener.2008.10.008.

19. Tian H, Mancilla-David F, Ellis K, Muljadi E, Jenkins P. 2012. A cell-to-module-toarray detailed model for photovoltaic panels. Sol Energy. 2012; 86:2695-706.

20. Boutana N, Mellit A, Haddada S. Rabhi A, Massi Pavan A. An explicit I-V model for photovoltaic module technologies, Energy Conversion and Management. 2017; 138:400-412.

21. Supriyono, Hassan Khamis Hassan, Marwan Effendy. Smart Detection of Sunlight using Arduino on Solar Power Systems. Test engineering\& Management. 2019;81:6576-6584.

22. Gairaa K, Khellaf A, Messlem Y, Chellali Y. Estimation of the Daily Global Solar Radiation Based on Box-Jenkins and ANN Models: A Combined Approach. Renewable and Sustainable Energy Reviews. 2016;57:238-249.

23. Guermoui, Mawloud, Abdelaziz Rabehi. Soft Computing for Solar Radiation Potential Assessment in Algeria. International Journal of Ambient Energy. 2018;41(13).

https://doi.org/10.1080/01430750.2018.1517686.

24. Zaghba L, Khennane M, Hadj Mahamed I, Oudjana HS, Fezzani A, Bouchakour A, Terki N. A combined simulation and experimental analysis the dynamic performance of a $2 \mathrm{~kW}$ photovoltaic plant installed in the desert environment, Int $\mathrm{J}$ Energy Environ Eng. 2016;7:49-260. https://doi.org/10.1007/s40095-0160216-2.

25. Zaghba L, Khennane M, Terki N, Borni A, Bouchakour A, Fezzani A, Hadj Mahamed I, Oudjana $\mathrm{SH}$. The effect of seasonal variation on the performances of grid connected photovoltaic system in southern of Algeria. AIP Conference Proceedings 2017;1814:020005. https://doi.org/10.1063/1.4976224.

26. Sahouane N, Dabou R, Ziane A, Neçaibia A, Bouraiou A, Rouabhia A, Mohammed B. Energy and economic efficiency performance assessment of a 28 $\mathrm{kWp}$ photovoltaic grid connected system under desertic weather conditions in Algerian Sahara. Renewable. Energy. 2019;143:1318-1330 https://doi.org/10.1016/j.renene.2019.05.086.

Received 25.11.2020

Accepted 2021-04-20

Available online 2021-04-22

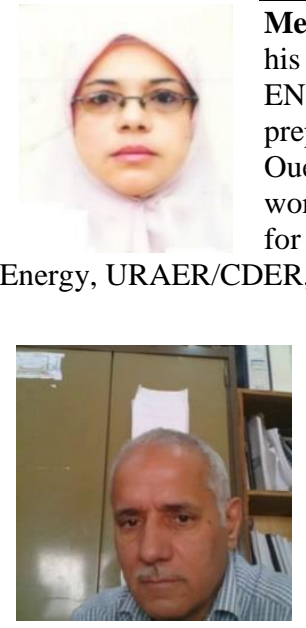

Messaouda KHENNANE received his MSc in Electrotechnics from the ENP, Algeria. Currently, he is preparing his Doctoral thesis on the Ouergla university in Algeria and is working as a researcher at the Unit for Applied Research in Renewable

Slimane BOUGHALI, professor of Physics, Kasdi Merbah University Ouargla, His research interests concern: heat transfer energy storage dessalination dryingsolar energy

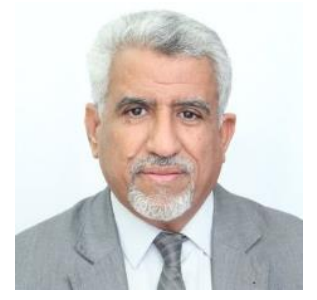

Bechki DJAMEL, professor of Physics, Kasdi Merbah University Ouargla, Algeria, His research interests concern: heat transfer energy storage dessalination dryingsolar energy.

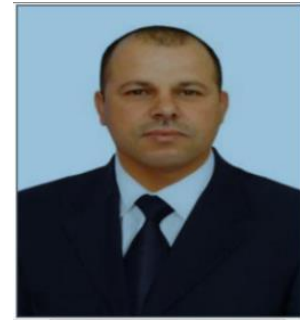

Layachi ZAGHBA received his Diploma in Automatic Engineering in 2002 and MSc in Electronics in 2005 from the Science and Technology Department of Jijel University. He received his $\mathrm{PhD}$ in Electrical Engineering (Automatic) from the University of Biskra, Algeria, in 2017. Currently, he is a researcher at the Unit for Applied Research in Renewable Energy (URAER), Ghardaia, Algeria.His main interest areas are the photovoltaic systems and their applications,control, optimisation, performance analysis of grid connectedphotovoltaic.

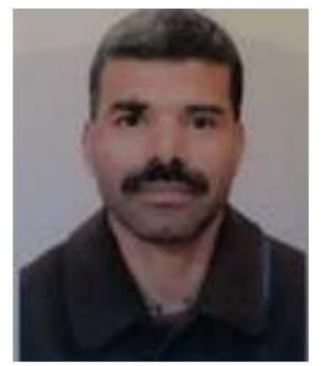

Amor FEZZANI was born in Batna (Algeria), on September 9, 1971. He graduated from the El Hadj Lakhda. University (Algeria) in 1996 with electrical engineering degree. He received M.Sc. and Ph.D degrees in electrical engineering, from the University of Batna, Algeria, respectively in 2009 and 2015. Currently, he is researcher at the Unité de Recherche Appliquée en Energies Renouvelables, URAER, Centre de Développement des Energies Renouvelables, CDER, Alegria. His research interests concern: renewable energy, power electronics, electric machines, robust control, etc.

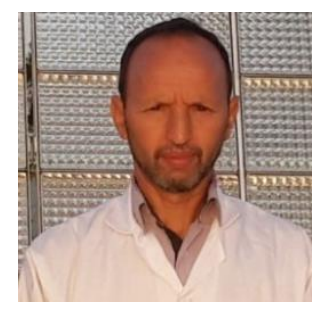

Idriss Hadj MAHAMMED received his $\mathrm{MSc}$ in Electrotechnics from the ENP, Algeria. Currently, he is preparing his Doctoral thesis at the Bejaia University, Algeria and is working as a researcher at the Unit for Applied Research in Renewable Energy,

URAER/CDER, Ghardaia, Algeria 